\title{
Teacher Job Performance: The Role of Head Teachers' Supervisory Styles in Public Basic Schools in Mankessim Circuit
}

\author{
Alex Kojo Appiah: Catholic Girls’ School, Saltpond, Ghana. \\ -Kweku Esia-Donkoh: University of Education, Winneba, Ghana.
}

\begin{abstract}
The study investigated the effect of head teachers' supervisory styles and teachers' job performance in public basic schools in the Mankessim Education Circuit of the Mfantseman Municipality in the Central Region of Ghana. A descriptive survey in the form of mixed methods was used for the study. Through purposive and stratified sampling techniques, 134 respondents made up of 16 head teachers, and 118 teachers were selected and engaged in the study. Two sets of questionnaires, one each for head teachers and teachers were used to collect quantitative data. Qualitative data were obtained through a semi-structured interview guide from 10 respondents (headteacher and teachers) who were conveniently sampled. Means, standard deviation, $t$-test, one-way ANOVA, and multiple regression were used to analyze the quantitative data while content analysis was used to analyze the qualitative data. The study revealed that head teachers used directive control supervisory style most frequently as compared to collaborative, directive informational, and non-directive supervisory styles. Generally, teachers' job performance was very good. Besides, the study discovered that head teachers' supervisory styles were good predictors of teachers' job performance. It was concluded that supervisory styles of head teachers were essential factors that influenced teachers' job performance in schools. Among the recommendations is that in-service training in the form of workshops and seminars should be organized for both head teachers and teachers on the need for effective supervision in public basic schools in the Circuit to achieve school and educational goals.
\end{abstract}

Key words: Headteachers, Teachers, Supervisory styles, Job performance, Public, Basic schools.

\section{Introduction}

It is widely acknowledged among scholars in education that education is crucial in the attainment of socio- economic growth and technological progress. This is why (Onyesom \& Ashibogwu, 2013) observe that education is the pillar around which the progress of industrialized nations revolves. It is for this reason that in Ghana, the provision and support for education are enshrined in the 1992 Constitution as a basic human right for all Ghanaians (Agbenyega, 2007). Understandably, developing countries are required to design and implement progress-driven education systems if they desire to compete and survive in this ever-changing knowledge-based economy, and safeguard the statutory rights of the citizenry.

Accordingly, countries, including Ghana, have undertaken policy initiatives in the quest to expand education for all citizens. These policies include Education for All (EFA) in 1990, as an international initiative to bring the benefits of education to every citizen in every society, the United Nations' Millennium Development Goals (MDG) in 2000, which among other things, on education (MDG 2), which encourages governments worldwide to prioritise the provision of primary education in policy programmes as outlined in MDG 2 (UNESCO, 2006), and more recently, the Sustainable Development Goals (SDGs), which is expected

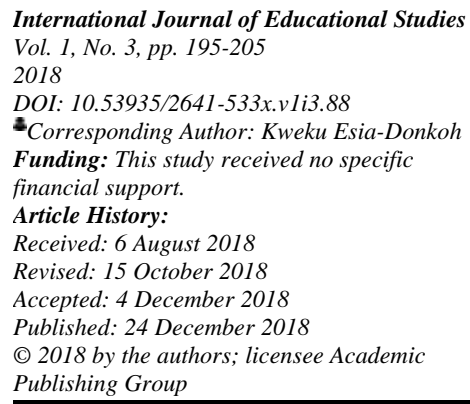


to guide countries to achieve social and economic development by 2030 (De, 2016). Like other countries, the government of Ghana is committed to achieving these global targets and as such, has formulated and implemented policies to increase access to basic education.

However, Buregeya (2011) observes that international and local educational policies have brought forth significant challenges to many education systems worldwide, including increased enrolment and poor academic performance. Intuitively, the essence of these policies would be negated if efforts are not made to improve other quality indicators, a view supported by Staff (2011) when he notes that quantitative expansion to provide education to all children of school-going age under EFA initiative should not in any circumstance, compromise other quality indicators. It has been established through research that supervision is one of the major strategies to ensure quality education. The World Bank (2010) observes that systems of supervision and support to schools are common areas of reform employed by world nations to improve their education outcomes and mitigate education challenges associated with global education policies. Similarly, Muthoni (2012) asserts that since the 1990s, many countries have attempted to reform supervision because of its effectiveness as a key tool in monitoring and improving education quality. Thus, the value of education supervision lies in the improvements of teaching and learning situations and consequently student achievement. As such, it could be inferred that supervision is indispensable in the effective and successful implementation of educational policies and enhance the provision of quality education.

Globally, headteachers have been acknowledged as the chief instructional leaders of their schools and are recognised as pivotal in promoting effective supervision of schools (Baffour-Awuah, 2011; Glickman, Gordon, \& Ross-Gordon, 2001; Gregory, 2010). Baffour-Awuah (2011) therefore asserts that in Ghana, headteachers of basic schools use instructional supervision to improve teaching and learning by providing practicing teachers with ongoing support and guidance for the benefits of students. It is therefore imperative for measures to be put in place to improve supervisory practices of headteachers to attain school and educational goals. In view of this, nations have designed policies which have been directed at the supervisory roles of school headteachers and this shows how important supervision is as an integral part of the daily process and operation in schools (Sharma, Yusoff, Kannan, \& Baba, 2011).

The concept of supervision is not new and as a result many scholars have given various definitions. Ogbo cited in Ikegbusi and Eziamaka (2016) maintains that supervision is the maximum development of the teacher into the most professionally efficient and effective person he or she is capable of becoming. According to Burton, Carper, and Wilburn (2011) supervision is defined as "efforts taken by the principal to support teachers and provide resources, including professional development, to facilitate teacher improvement". Eya and Chukwu (2012) substantiate this by explaining supervision as any programme which helps teachers to achieve both quantitative and qualitative instructional delivery. Bore cited in Kipngeno (2014) intimates that supervision is an act of encouraging human relations and teacher motivation. Sullivan and Glanz (2009) also define supervision as a "process of engaging teachers in instructional dialogue for the purpose of improving teaching and increasing student achievement".

From these definitions, it could be deduced that supervision is a continuous series of activities aimed at improving instructions and teachers' professional development which in turn enhances students' academic achievement. It assumes that the teacher has the potentials and that he or she needs help, guidance and direction to improve on his or her performance. Hence, the process of supervision should be collegial, collaborative, and foster warm relationship among the actors. As such, supervisors need to respect and tolerate the capacities of teachers, and work with them to boost their instructional delivery. Thus, the essential function of the supervisor is to help teachers to become efficient and effective in performing their duties (Mecgley, cited in Ikegbusi and Eziamaka (2016)). Supervision, therefore, is an activity of promoting leadership and teacher growth in the practice of education.

It is clear that supervision performs vital functions in educational institutions. It improves instruction, enhances professional growth of teachers, strengthens human relations, and promotes curriculum development (Behlol, Yousuf, Parveen, \& Kayani, 2011; Sidhu \& Fook, 2010; Wadesango, 2011). Gamage, Adams, and McCormack (2009) also indicate that the practice of providing feedback and monitoring have significant impact on the teachers performance. This suggests that instructional leaders should spend more time in the observation process to give enough feedback to teachers to improve on their performance (Chang, 2001). Tracey (2000) however, argues that poor supervision opens the door for unethical behaviours within an

institution and diminishes employee performance. Thus, inappropriate supervision could result in tardiness,

Vol. 1, No. 3, pp. 195-205

2018

DOI: 10.53935/2641-533x.v1i3.88

Corresponding Author: Kweku Esia-Donkoh Funding: This study received no specific Article History:

Received: 6 August 2018

Revised: 15 October 2018

Accepted: 4 December 2018

Published: 24 December 2018

(C) 2018 by the authors; licensee Academic

Publishing Group

| 196 
and malingering which cumulatively affect teacher job performance. Literature has revealed that even though both teachers and supervisors benefit from the supervisory process, students are the key recipients of the outcome of good supervision. Accordingly, supervisors and supervisees need to draw from the strengths of each other to attain desirable results for students.

This study was underpinned by Glickman, Gordon, and Ross-Gordon (1998) developmental supervision which recognises teachers as individuals who are at different stages of development. As such, some kind of supervision is suitable and beneficial to some teachers while other teachers may benefit from different supervisory models. This implies that supervision should be tailored to the peculiar needs of the supervisees based on their level of development. According to Glickman et al. (1998) the major issues underlying developmental supervision are: teachers function at different levels of professional development because they operate at different levels of abstract thinking, ability, and effectiveness; there is a need to supervise teachers in different ways; and the long-range goal of supervision should be to increase teachers' abilities in higher stages of thought.

Glickman et al. (1998) identified four styles supervisors may employ under developmental supervision. These are directive control, directive informational, collaborative style, and non-directive style of supervision. The directive control approach to supervision assumes that the supervisor has greater knowledge and expertise regarding an issue or the supervisee (teacher) lacks the appropriate skills within a given situation. Thus, the supervisor has all the control and teachers must adhere to the process set by the supervisor (Sullivan \& Glanz, 2009). The directive control supervision is generally used by supervisors who do not want opposing views. The directive control may be used when a teacher refuses to comply with a school policy. In this approach, the final decision always lies with the supervisor. Directive control supervision is also used when either the teacher is very new and needs more directive guidance, or when the teacher is struggling and needs close monitoring or guidance. It helps in controlling teacher actions and ends with the supervisor making the final decision.

Non-directive supervisory style engenders actions by the supervisees and assists them to think through consequences, and create their own action plans. Dawursk (2011) indicates that in non-directive supervision, teachers creates their own plan since they have the capability to self-analyse, self-critique, and implement viable solutions on their own. This form of self-direction is based on teachers' intrinsic desire for improvement and positive change and necessitates that teachers see the need for change. The non-directive approach is considered with experienced teachers who are able to regulate themselves within the common instructional goals. With the non- directive approach teachers are able to determine their own plans with some assistance by use of behaviours such as listening, reflecting, clarifying, encouraging, and problem-solving. It is therefore used when teachers possess greater expertise, commitment and responsibility for a decision than the supervisor does. The non-directive supervision is considered as the approach with the lowest level of supervisor intervention.

Directive informational supervision gives teachers more control of their own evaluation process. Sullivan and Glanz (2009) explain that goal setting is a part of this type of supervision. Supervisors set goals for teachers and offer a list of options for achieving the goals. Teachers are allowed to choose from the list of options set by the supervisor, and the process or procedure that they would prefer. The directive informational supervision approach is used to guide new teachers as they become more familiar and confident in their teaching styles and strategies. In this case, the supervisor constantly takes a very active role in terms of framing the direction and choice of the teacher, but primarily responsible for all aspects of supervision. Directive informational supervision is generally used when teachers are at relatively low developmental levels or when they are confused about what to try in their classrooms. The supervisor still retains the expert role in providing choices. In this way, the success of the selected choice is still the responsibility of the supervisor.

In the collaborative approach, there is listening, presenting, problem solving, and negotiating, where the supervisor and teacher propose alternative actions for improvement, discuss and alter actions until a joint plan is agreed upon. Decisions are arrived at jointly by clarifying, listening, reflecting, presenting, problem solving, negotiating and standardizing. This approach is mainly used when supervisors and teachers seem to have similar levels of expertise, involvement and concern with a problem. Its purpose is to provide for cooperation and equal decision-making. Dawursk (2011) agrees that the approach allows the supervisor and the teacher to negotiate a plan of action where neither side's viewpoint is excluded. Hence, they both share

the responsibility in its completion. This approach is a more preferred method of supervision as it allows

Vol. 1, No. 3, pp. 195-205

2018

Corresponding Author: Kweku Esia-Donkoh Funding: This study received no specific financial support.

Received: 6 August 2018

Revised: 15 October 2018

Accepted: 4 December 2018

Published: 24 December 2018

(C) 2018 by the authors; licensee Academic

Publishing Group

| 197 


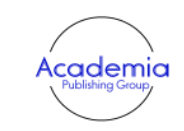

International Journal of Educational Studies Vol. 1, No. 3, pp. 195-205 2018

DOI: 10.53935/2641-533x.v1i3.88

"Corresponding Author: Kweku Esia-Donkoh Funding: This study received no specific financial support.

Article History:

Received: 6 August 2018

Revised: 15 October 2018

Accepted: 4 December 2018

Published: 24 December 2018

(C) 2018 by the authors; licensee Academic

Publishing Group

| 198 supervisors to express their opinion and participate in the problem solving but does not mandate their way as the only way. Ownership of the plan and proposed solution is shared by the supervisor and the teacher.

The collaborative approach is particularly helpful in areas where the supervisor is not an expert or have little or no experience. Through collaboration, the most informed individual expresses the knowledge but everyone participates in the decision making process. Collaboration is best used with teachers who are functioning at medium to higher developmental levels or when the supervisors and the teachers have relatively equal expertise regarding an issue. In the collaborative approach, both the supervisor and the teacher are held responsible for the outcomes. However, one major concern in supervisors utilizing this type of approach is developing a true collaborative relationship. Supervisors who withhold power during the collaboration aspects of this approach will undermine their attempt at collaboration (Glickman, Gordon, \& Ross-Gordon, 2004). According to Tyagi (2010) collaborative approach to supervision concentrates on the professional development of teachers to enhance their job performance.

Literature reveals that supervisors use varying types of styles in their supervisory activities. Thobega (2006) discovered that the supervisors most frequently used non-directive supervision where it was revealed that $34.6 \%$ of respondents rated their supervisors as non-directive, followed by directive informational supervision (33.3\%), collaborative supervision (28.4\%), and directive supervision (3.7\%). Similarly, Thobega and Miller (2008) established that supervisors were perceived to use mainly non-directive, collaborative, and directive-informational styles of developmental supervision, but a few used the directive style. It could be concluded from the findings of above studies that non-directive supervision is dominant among supervisors whilst the directive style is rarely used.

Several studies relating to teacher and supervisor preferences for developmental supervision practices have revealed conflicting results. For instance, Rossicone (1985) study revealed that $76 \%$ of the teachers preferred their supervisors to use a collaborative style, $20 \%$ preferred non-directive, and $4 \%$ preferred a directive style of supervision. In a similar study, Akinniyi (1987) found out that $75 \%$ of teachers preferred collaborative practices, $22 \%$ preferred the non-directive practice, and $3 \%$ preferred the directive approach. These studies indicate that, in general, teachers prefer a collaborative approach to supervision. However, Thobega and Miller (2007) concluded that teachers preferred non-directive over collaborative, directive informational, and directive styles of developmental supervision.

Besides supervision, scholars have noticed that teachers' job performance is critical to a schools success. Teachers play a critical role in nurturing the minds and the hearts of youth (Dike, 2009) and as a result, their job performance is crucial in achieving school and educational goals. Teachers are considered as the pivot of any educational system (Olorunfemi, 2008) and so their performance, is perhaps, the most critical factor that influences the development of education processes (Ikegbusi. \& Iheanacho, 2016). According to Ikegbusi.. (2014) teachers teach, train and process students to gain the needed life skills to make them responsible and contribute to their societies in the future.

Leithwood, Louis, Anderson, and Wahlstrom (2004)share the view of Ikegbusi.. (2014) by arguing that classroom practices of teachers have the most influence on student achievement. Thus, for schools to be effective, stakeholders need to look for opportunities to increase the professional development and job performance of teachers for the betterment in managing the teaching and learning process, and this can be done through supervision (Arong \& Ogbandu, 2010). The foregoing reiterate the truism that teachers are the bedrock of a school, and that their performance determines the success of the school. In this vein, the World Bank reports that around the world, teacher professional development is treated as a critical activity in the attainment of educational goals (Machio, cited in Kipngeno (2014)).

Teachers' job performance could be described as the duties performed by teachers at a particular period in the school system in achieving school goals. In this regard, Adeyemi (2010) defines teachers' job performance as the ability of teachers to combine relevant inputs for the enhancement of teaching and learning process. Adejumobi and Ojikutu (2013) support this claim when they note that teacher job-performance is one of the main factors that determines and affects school outcomes which could be measured through observing teacher activities in real classroom teaching performance, including lesson preparation, teacher commitment, extracurricular, supervision, effective leadership, motivation and morale.

From the definitions, it is evident that teacher job performance refers to the quantitative and qualitative accomplishment of tasks performed by teachers, and the desirable behaviours that they portray. Therefore, teachers' output of work in relation to lesson preparation, classroom teaching processes, regularity and 


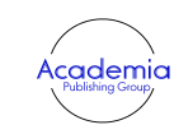

International Journal of Educational Studies Vol. 1, No. 3, pp. 195-205 2018

DOI: 10.53935/2641-533x.v1i3.88

"Corresponding Author: Kweku Esia-Donkoh Funding: This study received no specific financial support.

Article History:

Received: 6 August 2018

Revised: 15 October 2018

Accepted: 4 December 2018

Published: 24 December 2018

(c) 2018 by the authors: licensee Academic

Publishing Group

| 199 punctuality, time on task, and interpersonal relationship constitute their performance. For this study, issues of teachers' job performance (dependent variable) considered are teaching skills, management skills, discipline and regularity, and interpersonal relations.

The level of teacher job performance has become an issue of concern to education stakeholders with empirical studies establishing that teacher performance is not encouraging. Bolarinwa (2002) found out from a study in Nigeria that the level of teachers' job performance in schools was moderate. Oyewole and Popoola (2013) also discovered a moderate level of job performance among library personnel in Federal Universities and Federal Colleges of Education in Nigeria. Saka and Salman (2014) however, established that there was a high level of job performance of library personnel in universities in Nigeria. Literature show that supervision has an effect on teachers' job performance. Ogba and Igu cited in Ikegbusi and Eziamaka (2016) maintain that supervision is identified as one of the approaches to teacher effectiveness. Thus, the main outcome of supervision is to help teachers improve their performance by improving on what they already know, their teaching skills and their ability to make informed professional decisions (Sergiovanni \& Starratt, 2006).

Many researchers believe that supervision of instruction could improve classroom practices, and contribute to student success through professional growth and improvement of teachers' effectiveness and job performance (Mpofu, 2007). Nolan and Hoover (2008) contend that instructional supervision that focuses on teacher growth can bring about improvement in teacher performance and greater student learning. Ikegbusi and Eziamaka (2016) study revealed a great impact of internal and external supervision on teacher effectiveness in secondary schools. Hoojqan, Gharamani, and Safari (2015) realised a significant relationship between educational supervision and guidance, and improving teaching methods of guidance teachers. Similarly, Obakpolo and Osakwe (2015) established a significant relationship between supervision and teachers' effectiveness in public secondary schools in Delta State.

The rapid increase in enrolment in Ghanaian basic schools as a result of the implementation of policies such as Free Compulsory Basic Education (FCUBE), EFA, MDGs, and interventions like Capitation Grant and School Feeding Porgramme have resulted in increased demand for classroom teachers and high expectations from teachers in terms of their job performance. Empirical evidence indicates that there has been a remarkable drop in the academic performance of public basic school pupils in Ghana (Etsey, Amedahe, \& Edjah, 2005). This seems to be confirmed by the poor performance of pupils in the Basic Education Certificate Examination (BECE) in the Mfantseman Municipality of which Mankessim Education Circuit is part.

Statistics show that $47.2 \%$ of pupils passed the BECE in $2010,36.8 \%$ in $2011,48.2 \%$ in $2013,53.2 \%$ in $2015,64.4 \%$ in 2016, and $54.4 \%$ in 2017. The performance of pupils in the BECE in the Mankessim Education Circuit has also not been encouraging within the same period. Deductively, many pupils who wrote the BECE between 2010 and 2017 in the Circuit, and generally in the Municipality, could not access education at the Senior High School level. This trend of performance, no doubt, has become an issue of concern to stakeholders of education in the Mankessim Education Circuit and the Municipality as a whole.

Poor supervision has been identified as one of the causes of poor academic performance of pupils. For instance, Etsey et al. (2005) established from their study that in Ghana, academic performance is better in private basic schools than public basic schools as a result of more effective supervision of teachers' work. Oduro (2008) also found out that poor pupil performance in public schools, in part, is the result of ineffective supervision of teachers. Having established that supervision is directly linked with teacher job performance and student outcome (Nolan \& Hoover, 2008) poor student performance in public basic schools in the Mankessim Education Circuit of the Mfantseman Municipality could be attributed to poor teacher performance as a result of ineffective supervision. However, research into supervisory styles of headteachers and its effect on teacher job performance is rare in the Mankessim Education Circuit. This study, was therefore, conducted to fill this gap.

The findings of the study could help headteachers in public basic schools in the Circuit to be aware of their supervisory styles and the degree to which they impact teachers' job performance. This would guide them to either strengthen the practice of their supervisory styles or modify them when and where necessary. It is anticipated that the results of the study would inform both headteachers and teachers on the level of teachers' job performance, and evolve measures to improve upon it. Besides, it will help the supervision unit and the directorate to prescribe effective supervisory styles that are required to increase teacher job 
performance. Furthermore, this study would make an original contribution to the field of supervision and teacher job performance, and serve as reference material for future research.

\section{Research Questions}

i. What supervisory style(s) do headteachers practise in Mankessim Education Circuit?

ii. What is the level of teacher job performance in Mankessim Education Circuit?

iii. What is the effect of headteachers' supervisory styles on teachers' job performance in Mankessim Education Circuit?

\section{Methodology}

A cross-sectional survey design (Creswell \& Creswell, 2018) was used where both quantitative and qualitative data were collected concurrently. By this, both quantitative and qualitative data were collected concurrently after which the data were analysed separately and compared. The target population was all headteachers and teachers in public basic schools in the Mankessim while the accessible population was all headteachers and teachers in public basic schools in the Mankessim Education Circuit who had worked in their respective schools for at least one year. This in the view of the researchers was enough for the respondents to provide the needed information on the headteachers' supervisory styles and teacher job performance as it pertains in their schools. Purposive and stratified sampling techniques were used to select 134 respondents ( 16 headteachers and 118 teachers) for the quantitative phase of the study. For the qualitative aspect of the study, 15 respondents, made up of five headteachers and 10 teachers, were conveniently selected. Headteachers Supervisory Styles Questionnaire (HSSQ) and

Teachers Job Performance Questionnaire (TJPQ) were adapted for the study. The semi-structured interview guide was designed by the researchers. The pre-test of the two sets of questionnaires was carried out in Saltpond Education Circuit because it was considered to have similar characteristics with Mankessim Education Circuit. The analysis of the pre-test of the HSSQ showed Cronbach alpha coefficients of 0.76, 0.78, 0.82 , and 0.75 for directive control, directive informational, collaborative, and nondirective supervisory styles respectively, and a coefficient of

0.78 for overall supervisory styles. For the TJP scales, Cronbach alpha coefficients of $0.75,0.77,0.76$, and 0.79 were obtained for teaching skills, management, discipline and regularity, and interpersonal relations respectively, while

0.77 as realised for overall teacher job performance.

\section{Results and Findings}

Mean, standard deviation, t-test, analysis of variance (ANOVA), Pearson Product Moment correlation, and multiple regression were used to analyse the quantitative data while the qualitative data was analysed by using thematic analysis.

\subsection{Supervisory Styles of Headteachers}

In answering Research Question 1, the interpretation of the mean values were: Never (0.1-1.0); Seldom (1.1- 2.0); Sometimes (2.1-3.0); Often (3.1-4.0); and Always (4.1-5.0). Data in Table 1 helped to answer the question.

Table-1. Mean and Standard Deviation for Supervisory Styles of Headteachers.

International Journal of Educational Studies Vol. 1, No. 3, pp. 195-205 Vol. 1 . DOI: 10.53935/2641-533x.v1i3.88 "Corresponding Author: Kweku Esia-Donkoh Funding: This study received no specific financial support. Article History:

Received: 6 August 2018

Revised: 15 October 2018

Accepted: 4 December 2018

Published: 24 December 2018

(C) 2018 by the authors: licensee Academic

Publishing Group

\begin{tabular}{lll}
\hline Variables & Mean & Std. Deviation \\
\hline Directive Control Supervisory Style & 4.13 & 0.62 \\
Collaborative Supervisory Style & 3.96 & 0.68 \\
Directive Informational Supervisory Style & 3.76 & 0.54 \\
Nondirective Supervisory Style & 3.11 & 0.50 \\
Overall Supervisory Style & 3.74 & 0.45 \\
\hline
\end{tabular}

The results in Table 1 show that headteachers in public basic schools in Mankessim Education

Circuit always used directive control supervisory style $(\mathrm{M}=4.13, \mathrm{SD}=0.62)$, but often used collaborative $(\mathrm{M}=3.96, \mathrm{SD}=0.68)$, directive informational $(\mathrm{M}=3.76, \mathrm{SD}=0.54)$, and non-directive $(\mathrm{M}=3.11, \mathrm{SD}=0.50)$ 
supervisory style. Collectively, all the supervisory styles yielded a mean of $3.74(\mathrm{SD}=0.45)$. Although the directive control supervisory style was dominant among the headteachers, the results suggest that the headteachers often practiced all the supervisory styles in their schools. Analyses of the interview data revealed that headteachers used varied supervisory styles in their schools. Below are excerpts from the interview responses on supervisory styles mostly used by the headteachers:

My headteacher uses different approaches in the supervision of the school. Sometimes, he asks us to express our views on issues relating to supervision in the school while at other times, he controls what is to be done and we have to comply (Teacher \#3).

I take charge of supervision in my school because it requires that an experienced and competent person should assist others to improve on their performance. However, during the process, I engage my teachers and we share ideas to determine what works best in our school (Headteacher \#2).

Supervision is the responsibility of the head teacher, so I decide the activities for supervision. I do this because I always direct my activities to overcome the difficulties teachers face in their work so that there will be improvement (Headteacher 1\#).

It could be deduced from the above assertions that primarily, head teachers practiced the directive supervisory style more frequently. Besides, the data revealed that the collaborative style was also used often by the head teachers.

\subsection{Level of Teachers' Job Performance}

In answering Research Question 2, the level of teachers' job performance, as shown in Table 3, was interpreted based on the suggestion of Underwood (2004) as indicated in Table 2.

Table-2. Interpretation of Level of Job Performance

\begin{tabular}{lll}
\hline Scale & Range & Level of Performance \\
\hline 1 & $0.00-1.49$ & Poor \\
2 & $1.50-2.49$ & Fair \\
3 & $2.50-3.49$ & Good \\
4 & $3.50-4.49$ & Very good \\
5 & $4.50-5.00$ & Excellent \\
\hline Source: Underwood (2004).
\end{tabular}

Table-3. Mean and Standard Deviation for the Level of Teachers' Job Performance.

\begin{tabular}{lll}
\hline Variables & Mean & Std. Deviation \\
\hline Teaching Skills & 3.95 & 0.37 \\
Management Skills & 4.01 & 0.51 \\
Discipline and Regularity & 3.97 & 0.47 \\
Interpersonal Relations & 4.04 & 0.38 \\
Overall Teacher Performance & 3.98 & 0.31 \\
\hline
\end{tabular}

Comparing the results in Table 3 to the criteria set by Underwood (2004) as contained in Table 2, it could be observed that the level of job performance of teachers in public basic schools in Mankessim Education Circuit in relation to teaching skills $(\mathrm{M}=3.95, \mathrm{SD}=0.37)$, management skills $(\mathrm{M}=4.01, \mathrm{SD}=0.51)$, discipline and regularity $(\mathrm{M}=3.97, \mathrm{SD}=0.47)$, interpersonal relations $(\mathrm{M}=4.04, \mathrm{SD}=0.38)$, and the overall performance $(\mathrm{M}=3.98, \mathrm{SD}=0.31)$ was very good. This was corroborated by the responses from the interview as shown by the excerpts below:

I rate my teachers' level of job performance as very good because they prepare adequately for their International Journal of Educational Studies Vol. 1, No. 3, pp. 195-205 Vol. 1 . notice that they have patience to address individual challenges of the pupils (Headteacher \#1).

My performance as a teacher is good. I come to school early and every day, and I try to use instructional time judiciously. I teach, give exercises which I mark promptly and give feedback to my pupils. I take part in co- curricular activities such as sports, culture and the celebration of national festivals (Teacher \#2).

Aside my work as a teacher in the classroom, I co-operate with my colleagues in the work of the school. I think as an individual I may not be able to achieve much, but when we work together, there will be much 
improvement in our work. In my school, we relate well with each other, so we share ideas on the work we do. In all, I score my level of job performance as very good (Teacher \#4).

My teachers are disciplined in the work they do. They know what is expected of them as teachers, and they are punctual on tasks assigned them. They do not show favouritism among the pupils, and they use time wisely (Headteacher \#4).

The statements show that teachers displayed the different facets of job performance, especially in relation to management skills and interpersonal relationships.

\subsection{Effect of Headteachers' Supervisory Styles on Teacher Job Performance}

Data in Table 4 and 5 helped in answering Research Question 3, which sought to investigate the effect of headteachers' supervisory styles on teachers' job performance.

\begin{tabular}{|c|c|c|c|c|c|c|}
\hline Model & & $\begin{array}{l}\text { Sum } \\
\text { Squares }\end{array}$ & & $\begin{array}{l}\text { Mean } \\
\text { Square }\end{array}$ & $\mathbf{F}$ & Sig. \\
\hline \multirow[t]{3}{*}{1} & Regression & 6.6 .6 & 4 & 1.652 & 32.514 & 0.000 \\
\hline & Residual & 6.553 & 129 & 0.051 & & \\
\hline & Total & 13.159 & 133 & & & \\
\hline $\mathrm{R}$ & 0.709 & & & & & \\
\hline R Square & 0.502 & & & & & \\
\hline Adjusted R Square & 0.487 & & & & & \\
\hline Standard Error of the Estimate & 0.225 & & & & & \\
\hline
\end{tabular}

The multiple regression results as shown in Table 4 established that supervisory styles collectively accounted for $50.2 \%$ variance in teacher job performance which was found to be statistically significant [F $(4$, $129)=32.514, p=.000]$ at 0.05 . Therefore, the results suggest that headteachers' supervisory style is a good predictor of teacher job performance, and that other factors not included in this study could contribute $49.8 \%$ to teacher job performance. The study further examined the contribution of each of the supervisory styles to teacher job performance, and the results are presented in Table 5.

\begin{tabular}{|c|c|c|c|c|c|c|c|c|}
\hline \multirow{2}{*}{\multicolumn{2}{|c|}{ Model }} & \multicolumn{2}{|c|}{$\begin{array}{l}\text { Unstandardized } \\
\text { Coefficients }\end{array}$} & \multicolumn{3}{|c|}{$\begin{array}{l}\text { Standardized } \\
\text { Coefficients }\end{array}$} & \multicolumn{2}{|c|}{ Collinearity Statistics } \\
\hline & & B & Std. Error & Beta & $\mathrm{t}$ & Sig. & Tolerance & VIF \\
\hline \multirow[t]{5}{*}{1} & (Constant) & 2.191 & 0.198 & & 11.069 & 0.000 & & \\
\hline & DC & 0.171 & 0.033 & 0.336 & 5.273 & 0.000 & 0.953 & 1.049 \\
\hline & NDA & 0.108 & 0.021 & 0.348 & -5.132 & 0.000 & 0.841 & 1.189 \\
\hline & DI & 0.083 & 0.040 & 0.142 & 2.071 & 0.040 & 0.821 & 1.217 \\
\hline & $\mathrm{CA}$ & 0.281 & 0.031 & 0.605 & 9.015 & 0.000 & 0.856 & 1.168 \\
\hline
\end{tabular}

The data in Table 5 show that all the supervisory styles contributed significantly to teacher job performance. Indeed, the results indicate that headteachers' collaborative style $(\beta=0.605, t=9.015, p=0.000)$, directive control $(\beta=0.336, \mathrm{t}=5.273, \mathrm{p}=0.000)$, non-directive approach $(\beta=-0.348, \mathrm{t}=-5.132, \mathrm{p}=0.000)$, and directive informational $(\beta=0.142, \mathrm{t}=2.071, \mathrm{p}=0.040)$, made significant unique contribution to teacher job performance in the Mankessim Circuit. The following excerpts from the interview established an effect of headteachers' supervisory styles on teachers' job performance in public basic schools in the Mankessim Education Circuit:

My headteacher's supervisory activities have affected my performance. She relates her supervision to our work in the classroom, and she tries to address the difficulties we face in doing our work. I apply the ideas gathered after supervision in my work which always helps me to improve on my performance (Teacher \#3).

International Journal of Educational Studies 2018

DOI: 10.53935/2641-533x.v1i3.88

Corresponding Author: Kweku Esia-Donkoh Funding: This study received no specific Article History:

Received: 6 August 2018

Revised: 15 October 2018

Accepted: 4 December 2018

Published: 24 December 2018

(C) 2018 by the authors: licensee Academic

Publishing Group 
I believe my supervisory approach has influenced the teachers' performance greatly. My supervision is geared towards teacher development, and I make sure that it is done with the teacher in focus. By this, I cater for the needs of the teachers so that they can work effectively (Headteacher \#2).

My headteacher's supervision motivates me to do more as a teacher. During supervision, my head teacher points out my strengths and weaknesses, and addresses them which enable me to improve on my performance. By these, my head teacher's supervision has contributed immensely to my performance as a teacher (Teacher $\# 1)$.

The analysis of the interview data confirmed that the supervisory styles of the headteachers were instrumental in their teachers' job performance.

\section{Discussion}

The finding from the analysis of the quantitative data revealed that headteachers mostly used directive control supervisory style as compared to collaborative, directive informational, and nondirective supervisory styles. This is confirmed by the finding from the analysis of the interview data which portrayed that even though headteachers in public basic schools in the Mankessim Education Circuit utilised all the supervisory styles outlined in the study, they were found to dominantly use directive control supervisory style. This finding contradicts (Thobega \& Miller, 2007) finding which indicated that supervisors most frequently used non-directive style than the directive informational, collaborative, and the directive control supervision.

The study revealed that generally teachers' job performance in public basic schools in Mankessim Education Circuit was very good. This was observed from the analyses of both quantitative and qualitative (interview) data. This finding disagrees with that of Oyewole and Popoola (2013) who discovered a moderate level of job performance among library personnel in Federal Universities and Federal Colleges of Education in Nigeria. It also contradicts the findings of Bolarinwa (2002) which revealed that teachers' job performance was moderate and not to expectation in schools in Nigeria. However, the finding from the study seems to substantiate that of Saka and Salman (2014) whose study established a high level of job performance of library personnel in universities in Nigeria. The outcomes of this study suggest that teachers in the Mankessim Circuit showed very good performance in relation to teaching skills, management skills, discipline and regularity, and interpersonal relations better than their peers in Nigeria.

It was established that supervisory styles of headteachers had a significant effect on teachers' job performance as they collectively contributed a significant $50.2 \%$ to teacher job performance. This implies that other supervisory styles not included in this study could account for $49.8 \%$ of teachers' job performance. Interestingly, all the supervisory styles (collaborative, directive control, non-directive approach, and directive informational) made significant individual contribution to job performance. The results from the analysis of the interview data confirmed that supervisory styles contributed to teacher job performance. The findings of this study concur with previous findings of Ikegbusi and Eziamaka (2016); Hoojqan et al. (2015) and Obakpolo and Osakwe (2015) which indicated that supervision impacts teacher job performance.

\section{Conclusions and Recommendations}

Based on the findings from the study and the discussions, there is every proof that effective supervision through variety of supervisory styles by headteachers is crucial in improving teachers' performance which eventually helps to improve academic achievement of pupils. Thus, headteachers need to adopt and utilise appropriate supervisory styles that could help achieve optimal benefits from teachers to improve instruction. This calls for collaborative and collegial interaction between headteachers and teachers during the supervision process.

From the foregoing, it is recommended that the Ghana Education Service (GES) in the Mfantseman

International Journal of Educational Studies Vol. 1, No. 3, pp. 195-205 2018

DOI: $10.53935 / 2641-533 x . v 1 i 3.88$

Corresponding Author: Kweku Esia-Donkoh Funding: This study received no specific financial support.

Article History:

Received: 6 August 2018

Revised: 15 October 2018

Accepted: 4 December 2018

Published: 24 December 2018

(C) 2018 by the authors; licensee Academic

Publishing Group

$\mid 203$
Ficipality should organise regular workshops and seminars for headteachers in public basic schools in the

Mankessim Education Circuit. This will help them to advance their knowledge, skills, experience to enable them balance the use of supervisory styles in specific situations. Similarly, in-service training programmes in the form of workshops and seminars should be regularly organised by the GES in the Municipality for teachers in public basic schools in the Circuit on the needs of supervision in schools and what is expected of teachers during the supervision exercise. Again, similar studies should be conducted in other Education Circuits of the Mfantseman Municipality to gain a better understanding of the influence of headteachers' supervisory styles on teachers' job performance in the Municipality. 


\section{References}

Adejumobi, F. T., \& Ojikutu, R. K. (2013). School climate and teacher job performance in lagos state Nigeria. Discourse Journal of Educational Research, 1(1), 26-36.

Adeyemi, T. O. (2010). Principals' leadership styles and teachers' job performance in senior secondary schools in Ondo State, Nigeria. Journal of Education Administration and Policy Studies, 2(26), 83-91.

Agbenyega, J. (2007). Examining teachers' concerns and attitudes to inclusive education in Ghana. International Journal of Whole Schooling, 3(1), 41-56.

Akinniyi, G. O. (1987). Perceptions and preferences of principals' and teachers' supervisory behaviour Unpublished doctoral dissertation, University of wisconsin, Madison, WI. Dissertation Abstracts International, 48: 1936.

Arong, F. E., \& Ogbandu, M. A. (2010). Major causes of declining quality of education in nigeria administrative perspective, A case study of dekina local government area. Canadian Social Science, 6(3), 61-76.

Baffour-Awuah, P. (2011). Supervision of instructions in public primary schools in Ghana, Teachers and head teachers' perspectives. Retrieved from: http://www.researchrepository.murdoch.edu.au/8483/2/02Whole.pdf.

Behlol, M. G., Yousuf, M. I., Parveen, Q., \& Kayani, M. M. (2011). Concept of supervision and supervisory practices at primary level in Pakistan. International Education Studies, 4(4), 28-35.

Bolarinwa, N. (2002). Motivation and teachers job performance in secondary schools in lokoja local government area of Kogi State. An Unpublished M.Ed.

Buregeya, N. (2011). Influence of head teachers' general and instructional supervisory practices on teachers work performance in secondary schools in Entebbe Municipality.

Burton, L., Carper, K. C., \& Wilburn, V. (2011). The sociology of educational supervision and evaluation. Journal of CrossDisciplinary Perspectives in Education, 4(1), 24-33.

Chang, J. (2001). Instructional leadership in a pacific context. Washington, DC: Educational Resources Information Centre.

Creswell, J. W., \& Creswell, J. D. (2018). Research design, qualitative, quantitative, and mixed methods approaches (5th ed.). Los Angeles: SAGE.

Dawursk, G. (2011). Media's influence on youth. Retrieved from: http://www.yuthguy.com/Literature\%20Review.htm.

De, G. A. (2016). Educational planning for the 2030 agenda. International Institute for Educational Planning (IIEP), 32(2), 1-3.

Dike, V. E. (2009). Nigeria's teachers deserve better treatment. Retrieved from: http:// www.nigeriavillagessquare.com/articles/victordike.

Etsey, Y. K. A., Amedahe, F. K., \& Edjah, K. (2005). Do private primary schools perform better than public schools in Ghana? Unpublished Paper. Department of Education Foundations. University of Cape Coast: Cape Coast, Ghana.

Eya, P. E., \& Chukwu, L. C. (2012). Effective supervision of instruction in Nigerian secondary school, issues in quality assurance. Journal of Qualitative Education, 8(1), 1-6.

Gamage, D., Adams, D., \& McCormack, A. (2009). How does a school leader's role influence students' achievement? A review of research findings and best practices. NCPEA.

Glickman, Gordon, P., \& Ross-Gordon, J. M. (1998). Supervision of instruction. Needham heights, Massachusetts. USA: Ally \& Bacon.

Glickman, Gordon, S. P., \& Ross-Gordon, J. M. (2001). Supervision and instructional leadership (5th ed.). Boston, MA: Allyn \& Bacon.

Glickman, Gordon, S. P., \& Ross-Gordon, J. M. (2004). Super vision and instructional leadership, a developmental approach (6th ed.). New York: Pearson Education Inc.

Gregory, C. F. (2010). Institutional supervision, a descriptive study focusing on the observation and evaluation of teachers in cyber schools, Pennsylvania. Doctoral Dissertation. Indiana University: USA.

Hoojqan, A. R., Gharamani, J., \& Safari, S. A. (2015). The effect of educational supervision on improving teachers' performances in schools of Marand. Indian Journal of Fundamental and Applied Life Sciences, 5(52), 1731-1735.

Ikegbusi, N. G., \& Eziamaka, C. N. (2016). The impact of supervision of instruction on teacher effectiveness in secondary schools in Nigeria. International Journal of Advanced Research in Education and Technology, 3(3), 12-16.

Ikegbusi., N. G., \& Iheanacho, R. C. (2016). Factors militating against effective administration of secondary schools in Anambra state. World Journal of Educational Research, 3(1), 1-14.

Ikegbusi.., N. G. (2014). Towards enhancing staff personnel management in secondary schools in Anambra state. Journal of Educational Research, 2(3), 117-124.

Kipngeno, R. D. (2014). Factors influencing headteachers' instructional supervision practices in public primary schools in Longisa division, Bomet district. Master of Education Dissertation. University of Nairobi: Kenya.

Leithwood, K., Louis, K. S., Anderson, S., \& Wahlstrom, K. (2004). Review of research: How leadership influences student learning: New York: The Wallace Foundation.

Mpofu, L. C. (2007). Perception of classroom supervision by secondary school teachers in the Harare region. Masters Dissertation. Tshwane University of Technology.

Muthoni, A. (2012). A study of public secondary school teacher's attitudes towards school inspectors in Embu District.

Nolan, J. F., \& Hoover, L. A. (2008). Teacher supervision and evaluation, theory to practice (2nd ed.). Hoboken, NJ: John Wiley \& Sons, Inc.

Obakpolo, P., \& Osakwe, R. N. (2015). Supervision as a determinant of public secondary school teachers' effectiveness in central senatorial district of Delta state. IOSR Journal of Research and Method in Education, 5(5), 8-19.

Oduro, G. (2008). Increased enrolment does not mean quality education [Electronic version]. Retrieved from: http:news.myjoyonline.com/education/200809/20151.asp.

Olorunfemi, D. O. (2008). Challenges of instructional supervision in the new millennium, implication for effective planning. Journal of Multidisciplinary Studies, 3(2), 68-68. 
Onyesom, M., \& Ashibogwu, N. K. (2013). Towards quality assurance in business education in Nigeria, onstraints and control. Asian Journal of Business Management, 5(3), 306-312.

Oyewole, G. O., \& Popoola, S. O. (2013). Effects of psycho-social factors on job performance of library personnel in federal colleges of education in Nigeria. Retrieved from: http://www.unlibunl.edu/LPP.pdf.

Rossicone, G. N. (1985). The relationships of selected teacher background versus preferences for supervisory style and teacher perceptions of supervisory style of supervisors.

Saka, K. A., \& Salman, A. A. (2014). An assessment of the levels of job motivation and satisfaction as predictors of job performance of library personnel in Nigerian universities. Journal of Balkan Libraries Union, 2(2), 26- 33.

Sergiovanni, T. J., \& Starratt, R. (2006). Supervisio, a redefinition (8th ed.). New York: MacGraw-Hill.

Sharma, S., Yusoff, M., Kannan, S., \& Baba, S. B. (2011). Concerns of teachers and principals on instructional supervision in three Asian countries. International Journal of Social Science and Humanity, 1(3), 214-217.

Sidhu, K. G., \& Fook, Y. C. (2010). Formative supervision of teaching and learning, Issues and concerns for the school heads. European Journal of Scientific Research, 39(4), 589-605.

Staff, E. (2011). Access to education, Myth or reality in school? Group Work, 2(1), 59-82.

Sullivan, S., \& Glanz, J. (2009). Supervision that improves teaching: Strategies and techniques. Thousand Oaks, CA: Corwin Press.

Thobega, M. (2006). Perceptions of supervision practices by agricultural education student teachers. Journal of Agricultural Education, 65(49), 86-99.

Thobega, M., \& Miller, G. (2007). Supervisory behaviors of cooperating agricultural education teachers. Journal of Agricultural Education, 48(1), 64-74.

Thobega, M., \& Miller, G. (2008). Perceptions of supervision practices by agricultural education student teachers. Journal of Agricultural Education, 65(49), 65-75.

Tracey, D. (2000). Supervisory practices in schools. Journal of Agricultural Education, 65(49), 23-54.

Tyagi, R. S. (2010). School-based instructional supervision and the effective professional development of teachers compare. A Journal of Comparative and International Education, 40(1), 111-125.

Underwood, J. (2004). What's your corporate IQ? Chicago: Dearborn Trade Publishing.

Wadesango, N. (2011). Group work, Myth or reality in school based decision-making. Group Work, 21(1), 59-82.

World Bank. (2010). Education in Ghana, improving equity, efficiency and accountability of education delivery. Washington, DC: World Bank. 